\title{
Screening of some varieties of groundnut (Arachis hypogea L.) Against Rosette disease in Nigerian Sudan savanna
}

\author{
Hayatu, Mohammed ${ }^{2, ~ *}$, Kutama A. S. , Auyo, M. I. ${ }^{1}$, Umar S. ${ }^{3}$, M. L. Umar ${ }^{4}$ \\ ${ }^{1}$ Department of Biological Sciences, Faculty of Science, Federal University, Dutse, Jigawa state, Nigeria \\ ${ }^{2}$ Department of Plant Biology, Bayero University, Kano \\ ${ }^{3}$ Department of Biological Sciences, College of Arts, Sciences and Remedial Studies, Kano \\ ${ }^{4}$ Department of Plant Science, Institute for Agricultural Research, Ahmadu Bello University, Zaria, Nigeria
}

Email address:

haymoh2001@yahoo.com (Hayatu, M.), kutamasak@yahoo.com (Kutama A. S.)

\section{To cite this article:}

Hayatu, Mohammed, Kutama A. S., Auyo, M. I., Umar S., M. L. Umar. Screening of Some Varieties of Groundnut (Arachis Hypogea L.) Against Rosette Disease in Nigerian Sudan Savanna. Plant. Vol. 2, No. 2, 2014, pp. 14-19. doi: 10.11648/j.plant.20140202.11

\begin{abstract}
Rosette has been a constraint to the production of groundnut in the existing farming system which contributes to the poor productivity of this crop. This trial was conducted in the screen-house of IITA Kano station, Nigeria to screen some groundnut varieties to rosette disease. The following parameters were measured during the trial such as chlorophyll content, plant vigor, disease incidence, $50 \%$ day to flower and grain yield. The result showed that chlorophyll content of the varieties 19BT and ICGV-IS-07825 showed no significant difference in their measurement at 7 days after infestation. At 14 days 19BT, ICGV-IS-07825 and ICGV-IS-09011 measured low chlorophyll content and at 21 days after infestation the chlorophyll content of all the plants in the Trials measured slight difference. Slight difference was recorded in plant vigor for the spray Trial and the non-spray were almost the same 21 days after infestation. There was no disease incidence in the spray Trial. Four varieties 19BT, ICGV-IS-07825, ICGV-IS-08872 and ICGV-IS-09011 in the non-spray had highest disease incidence and ICGV-IS-09982 recorded least incidence. Number of first day and $50 \%$ day to flower was measured and the result showed that rosette does not have effect on flowering date of groundnut since the both Trial flowered at the same time. 19BT and ICGV-IS-08872 measured highest number in grains and pod weight. ICGV-IS-07825 and ICGV-IS09982 measured least in number of grains and in pod weight in both Trials. It is concluded that resistance to groundnut rosette lutoevirus (GRVA) is not currently available in cultivated groundnut. More concerted effects are required where management packages can be put into proper practice.
\end{abstract}

Keywords: Groundnut Varieties, Rosette, Screening, Sudan Savanna, Nigeria

\section{Introduction}

Groundnut rosette virus disease was reported first by Zimmermann in 1907, and is recognized as the most important virus disease of groundnut (Arachis hypogaea L.) in Africa south of the Sahara, including Madagascar. There are several reports on the various types of rosette disease and management of the disease by cultural practices, spraying with aphicides, and utilizing host-plant resistance. By 1983, three reports were published on the causal viruses of groundnut rosette. In 1995, rosette appeared in about one million ha of groundnuts in Nigeria [14] the overall loss in yield to this disease was estimated at over 570000 tones at that period. It is presently grouped as the most destructive of all groundnut viruses in Africa. The export of groundnuts accounted for $22 \%$ of the national annual export value between 1962 and 1972 [2]. This made Kano city famous for its groundnut pyramids. Later on, the production started to decline from peak productions of the 1960s due to severe biotic constraints, which included diseases caused by fungi and viruses. Groundnut rosette disease is transmitted by Aphis craccivora according Koch and the virus/vector relationship, first investigated over 30 years ago, has been shown to be of the persistent one [20]. Although some researcher has achieved successful sap transmission of groundnut rosette virus, others were unable to transmit groundnut rosette virus by mechanical sap inoculation. Groundnut rosette virus can also be transmitted by graft inoculation mechanism. Prior to 1983, little knowledge was 
known about the causal viruses' of groundnut rosette disease. Rosette-infected plants were presumed to contain two viruses, one of which, groundnut rosette virus (GRV), was the major or only cause of symptoms in groundnut but was dependent on the other, groundnut rosette assistor virus (GRAV), for transmission by aphids. In 1981, rosetteinfected groundnut materials were processed in the virus unit of the Institute for Virus Research in Braunschweig, Federal Republic of Germany, by Dr R. Casper and his colleagues. In 1982, an ICRISAT Research Associate was sent to Worl in Braunschweig for 3 months to assist in characterizing the causal viruses. A luteovirus, serologically related to beet western yellows virus (BWYV) and to potato leaf roll virus (PLRV), was detected in both chlorotic and green rosette-infected groundnuts and was shown to be GRAV. Since the GRAV failed to produce typical groundnut rosette virus disease symptoms, it was evident that additional work would be necessary to isolate and characterize the symptom-inducing GRV [12].

In 1982, the U.S. Peanut CRSP initiated a project on the identification of groundnut viruses in Nigeria, with cooperation from scientists at the Institute for Agricultural Research (IAR) of Ahmadu Bello University, Samaru, Zaria, Nigeria. Characterization and diagnosis of the causal viruses of groundnut rosette is therefore very essential [8;19]. Resistance studies initially involving the screening of several groundnut lines in both greenhouse and field have been undertaken to determine the mechanisms of resistance to the rosette complex. These studies are yielding encouraging results.

The occurrence and incidence of rosette in relation to vector population dynamics in groundnut ecosystems is being studied with a view to achieving integrated control of the disease, using resistant or tolerant cultivars, and inexpensive systemic chemicals. Based on this work, definite statements can now be made on integrated control of the disease. Alternate hosts of the aphid and the virus are also being investigated. Epidemiological studies to determine the spread of green and chlorotic rosette viruses in several groundnut cultivars are being vigorously pursued with interesting results. A. craccivora is the most important pest of groundnuts in the tropics. Sap removal and physiological reactions of plants to aphid feeding cause direct damage. The removal of sap weakens the plant, causing poor and stunted growth, leaf curling and distorted leaf growth, wilting and reduced resistance to drought conditions, all resulting in yield losses [20]. Damage due to irritants and toxins, produced by aphid feeding on the leaves and growing points, manifests itself in necrosis and other adverse reactions. A brown necrosis may be induced in groundnuts, for example, while disturbances in fruiting and a reduction in the root system can occur. Direct feeding damage on groundnuts by large numbers of aphids can also result in partial sterility of plants [4].

Groundnut rosette virus (GRV) is a complex of at least five viruses, varying in distribution. GRV is transmitted in a persistent manner by A. craccivora, and may persist in aphids for more than 10 days. Groundnut rosette can cause serious morphological disturbances to groundnut plants, which take on a bushy appearance. Other symptoms include yellowing, mottling, leaf mosaic, and stunting and distortion of the shoots. It can account for extensive yield losses. If plants are infected when young, they may produce no nuts. The complex of GRV strains, along with an assistor luteovirus (GRAV) and satellite RNAs cause groundnut rosette disease. Distinct disease types have been recognized, dependent on the GRV strains involved: groundnut chlorotic rosette disease, groundnut green rosette disease and groundnut mosaic rosette disease [16].

Groundnut varieties resistant to GRV were found in Africa in the early 1950s. Systematic plant breeding programmes have been in operation since then [15]. In studies conducted in Nigeria, eight genotypes that were either resistant or susceptible to GRV were planted and infested with viruliferous $A$. craccivora. Infestation with rosette resulted in a seed yield 33 times higher in the resistant genotypes than in the susceptible ones, while yields were comparable in the two groups under rosette disease-free conditions [13]. It has been reported that GRV resistant varieties from one region in Africa may succumb if grown in another region [3]. The objective of this study was to screen some groundnut varieties against groundnut rosette disease in the Sudan savanna region of Nigeria.

\section{Material and Methods}

\subsection{Experimental Site}

The trial was conducted from October, 2012 to February, 2013 in a screen house of the International Institute of Tropical Agriculture (IITA), Kano Station.

\subsection{Seed Collection and Sowing}

Two hundred and fifty (250) seeds were collected from ICRISAT stored room. The seeds were stored in conducive environment of normal room temperature and properly packed in seed envelop. Each seed envelop contain 50 seeds of groundnut and correctly labeled. Pre-sowing treatment was done so as to ascertain the viability of the seeds. This was carried out for four days [9]. Sixty (60) plastics pots of seven liters (7L) were used for the experiment. The bottom of the plastics was perforated to achieve proper water drainage. The plastics were filled with two types of river sand and then watered for two days for adequate moisture before planting. White Board Marker of black color was used for labeling of the pots.

Planting of groundnut seed was done on the $18^{\text {th }}$ October, 2012 in the screen-house IITA, Kano station after preparation of the 60 plastic pots. The pots were watered for two days before planting. Four seeds were planted in each pot and thinning was carried out 21 days after seed germination. Each pot was thinned to two plants per pot for sufficient nutrient utilization. Five varieties of groundnut were selected at the ratio of $3: 2$. That is three resistance 
varieties and two susceptible varieties to rosette disease. ICGV- IS 08872 is resistant, ICGV- IS 07825 and ICGV- IS 09011. ICGV- IS 09982 is susceptible and ICGV- IS19BT is tolerant. Fertilizer was applied 48 days after seeds germination and the plants were watered every two days interval due to the dry season and late planting to avoid wilting [9].

\subsection{Experimental Design}

The experiment was carried out in Randomized Complete Block Design (RCBD) with two treatments; treated (spray) and non-treated (no-spray).

\subsection{Aphid Collection}

The sample of the vector Aphis craccivora was collected from IITA research farm Minjibir Kano with Petri-dish for the infestation. The Aphids usually attached on fresh pods of cowpea which make it easy for collection [10].

\subsection{Crop Infestation}

Inoculation was done by direct infestation of the vector (Aphis craccivora) which transmitted the virus after feeding on the plants for ten (10) minutes. This method of infestation is known as natural infestation in the screenhouse. The symptoms manifested 21 days after infestation $[5 ; 21]$.

\subsection{Data collection}

The following data were collected in both spray and nonspray trial.
i. Chlorophyll content (SPAD).
ii. Plant vigor
iii. Disease incidence
iv. Number of days to first flower
v. Number of $50 \%$ days to flower
vi. Grain yield of groundnut

\subsection{Chlorophyll Content}

Chlorophyll contents were measured using chlorophyll SPAD meter (Model: SPAD 502 PLUS). The measurements were carried out at different days after infestation. I.e. 7, 14 and 21 days after infestation. Three different leaves were picked at random and the average chlorophyll content was recorded [7].

\subsection{Plant Vigor}

Plant vigor was measured using a scale of 1-5 base on the physical appearance of the plant 1 means very poor, 2 poor, 3 average, 4 good and 5 very good [9].

\subsubsection{Disease Incidence}

The pathogen rosette virus was identified 21 days after infestation on the susceptible cultivar while the resistance cultivars showed no symptom. Both chlorotic and green rosettes appeared with wiled leaves, shorten internodes, mosaic and stunted growth. Each entry was assessed for disease incidence 60 days after sowing. The total number of plants in each plot and the number of plants showing rosette symptoms with severe stunting were counted and percentage of disease incidence computed [22].

\subsubsection{Number of Days to First Flower Opening}

Number of days to first flower was taken when there is appearance of first opening of flower pod. And this was computed in both trials [22].

\subsubsection{Number of 50\% Days to Flower}

Number of $50 \%$ days to flower was taken when all the plants in the plots flower at 50 percent. This was computed in both the spray and the non-spray trial [21].

\subsubsection{Grain Yield}

Grain yield was obtained when the plant reached physiological maturity for the harvest. After harvesting, pods are weighing and seeds were threshed and weighed using a digital weighing balance (Model: TH-5000) [17]

\subsubsection{Statistical Analysis}

Data collected were subjected to analysis of variance using two-way ANOVA. Procedure and GENSTAT software was used to analyze the raw data obtained [6]. Significant means were separated using least significant difference (LSD) at 5\%.

\section{Results and Discussion}

Groundnut rosette is regarded as a polycyclic disease because it spreads from primary sources of inoculums whose number increases during the growing season as progressively increasing numbers of plants become sources. Thus the number of groundnut plants in the trial with primary infections containing all three agents, the conditions which lead to development of vector progeny on these primarily infected plants, the density and transmission efficiency of infective vector populations in a given trial, and the number and frequency of inoculation events all influence whether all three agents are inoculated into each plant subsequently infested by these aphids. Each entry was assessed for disease incidence 60 days after sowing. The total number of plants in each plot and the number of plants showing rosette symptoms with severe stunting were counted and percentage of disease incidence computed. Plants showing severe symptoms were stunted and bushy in appearance due to reduced internodes length. Leaves of the infected plants were reduced in size and the plants did not produce pods this report is in line with the observation of [1;5]. Lines were considered resistant when no susceptible plants were found within the complete entry ( $0 \%$ incidence), highly susceptible when no resistant plants were present (100\% incidence) and moderately resistant when at least one plant within the entry has mild symptoms $(<50 \%$ incidence). This result agrees with the finding of [5; 18]. At harvest all plants in a plot were hand-lifted. Pods were 
separated from haulms and dried in the sun. The pods were weighed after cleaning with water and removal of soil and plant debris. The pods were package in seed envelop before been weighed with digital weighing balance in grams $(\mathrm{g})$. Both chlorotic and green rosettes were observed in all the susceptible varieties. But Green rosette symptoms were, however, predominant in the non-spray plot. The symptom was well pronouns on 19BT even though it produced the highest yield in the plot which shows that it may be probably tolerant to rosette disease. ICGV-IS-09982 produced the lowest yield and showed complete symptom of green rosette. In the spray plot 19BT produced the highest number of pod and grains and ICGV-IS-08872 in the same plot had no record of yield. This result is similar to that of [11]. The present study showed that resistance to rosette symptoms was not absolute since small portions of plants or a few branches of plants in resistant lines had rosette symptoms. All the genotypes resistant to groundnut rosette virus (GRV) were susceptible to GRAV indicating lack of resistance to this component of the rosette complex. The results indicated variability of the virus complex and probably the behavior of transmission efficiency of $A$. craccivora. Thus resistance to GRV could be overcome under high inoculums pressure or adverse environmental conditions $[12 ; 19]$. These results along with earlier reports $[1 ; 13]$ suggest that distinct mechanisms of resistance might operate against the three agents groundnut rosette umbravirus (GRV) and its satellite RNA, and GRAV) in the resistant material. An understanding of these mechanisms would enable the development of better strategies for incorporating resistance to all agents of rosette disease. Not only was the percentage of plants with disease symptoms lower in these selections, but also when symptoms did occur, they were of a mild nature to cause yield loss compared to the severe symptoms on susceptible checks. The impact of groundnut rosette on yield was demonstrated at ICRISAT screen house where the susceptible checks produced negligible pod yields. The results suggest that resistance to rosette disease in the genotypes tested is the result of physiological resistance. There was no significant difference in the chlorophyll content of the plants taken for 21 days as it did not affect the photosynthetic activities of the plants but there was a slight significant difference in varieties after 14 days of infestation as reported by [14;].

Novel sources of resistance have been identified in wild Arachis [15]. This sets the stage where useful germplasm within the wild species can be utilized to develop more stable sources of resistance to groundnut rosette virus. The non-spray trial flowered early than the spray trial probably the non-spray plot was under the pressure of the pathogen while the spray plot had enough time to grow and flower late probably due to a conducive environment. And also incidence of disease did not have effect on the flowering as both the susceptible and the non-susceptible flowered simultaneously. There is significant difference in the treatment of plant vigor but varieties and treatment by varieties has no significant difference. The number of grains and the pod weight has significant difference in their varieties while their treatment and treatment by varieties has no significant difference this corresponds with the observation of [7]. There is significant difference in the treatment of disease incidence but varieties and treatment by varieties, there is no significant difference. The result showed that all the resistance lines check were rosette which agrees with the observation of [9].

\section{Conclusion}

From the results of the study it is evident that resistance to groundnut rosette but immunity has been found in some promising varieties. Therefore all resistant material needs to be evaluated for performance against a range of variants of groundnut rosette disease agents in different environmental conditions.

Table 1. chlorophyll content (SPAD) of some groundnut varieties at different days after infestation

\begin{tabular}{|c|c|c|c|c|c|c|}
\hline & 7D & & $14 \mathrm{D}$ & & 21D & \\
\hline Varieties & Spray & non spray & Spray & non spray & SPRAY & non spray \\
\hline 19BT & 39.3 & 36.6 & 39.8 & 37.1 & 36.2 & 34.2 \\
\hline ICGV-IS-07825 & 39.3 & 35.7 & 36.4 & 32.5 & 38.5 & 32.1 \\
\hline ICGV-IS-08872 & 34.7 & 45.8 & 32.1 & 44.9 & 31.7 & 38.4 \\
\hline ICGV-IS-09011 & 38.9 & 39 & 40.7 & 38.8 & 33.2 & 34.1 \\
\hline ICGV-IS-09982 & 34.5 & 31.8 & 31.2 & 25.8 & 32.3 & 29.3 \\
\hline Mean & 37.3 & 37.8 & 36 & 35.8 & 34.4 & 33.6 \\
\hline \multicolumn{7}{|l|}{ L.S D (5\%) } \\
\hline Treatment & & 4.79 & & 5.07 & & 4.59 \\
\hline Varieties & & 7.58 & & 8.02 & & 7.25 \\
\hline Treatment by varieties interactions & & 10.72 & & 11.35 & & 10.25 \\
\hline
\end{tabular}


Table 2. Plant vigor score (1-5) of some groundnut varieties at 21days after infestation

\begin{tabular}{lll}
\hline Varieties & Spray & no spray \\
\hline 19BT & 3 & 3.83 \\
ICGV-IS-07825 & 2.83 & 4.33 \\
ICGV-IS-08872 & 3.83 & 4.33 \\
ICGV-IS-09011 & 2.67 & 4.17 \\
ICGV-IS-09982 & 2.83 & 4.5 \\
Mean & 3.03 & 4.23 \\
L.S D (5\%) & & \\
Treatment & & 0.733 \\
Verities & & 1.159 \\
Treatment by varieties interactions & 1.638 \\
\hline
\end{tabular}

Table 3. Number of days to first flower of some groundnut varieties as affected by Rosette

\begin{tabular}{lll}
\hline Varieties & Spray & no spray \\
\hline I9BT & 25.33 & 25.67 \\
ICGV-IS-07825 & 25.17 & 21.83 \\
ICGV-IS-08872 & 26.33 & 22.67 \\
ICGV-IS-09011 & 26.67 & 27.17 \\
ICGV-IS-09982 & 17.17 & 23.33 \\
Mean & 24.13 & 24.13 \\
L.S D (5\%) & & \\
Treatment & & 3.938 \\
Verities & & 6.227 \\
Treatment by varieties interactions & 8.806 \\
\hline
\end{tabular}

Table 4. 50\% day of flowering of some groundnut varieties as affected by Rosette

\begin{tabular}{lll}
\hline Varieties & Spray & no spray \\
\hline 19BT & 48.3 & 47.2 \\
ICGV-IS-07825 & 47.7 & 39.7 \\
ICGV-IS-08872 & 47.5 & 39.5 \\
ICGV-IS-09011 & 47.2 & 47.2 \\
ICGV-IS-09982 & 32.3 & 39.3 \\
Mean & 44.6 & 42.6 \\
L.S D (5\%) & & \\
Treatment & & 6.75 \\
Verities & & 10.68 \\
Treatment by varieties interactions & 15.1 \\
\hline
\end{tabular}

Table 5. Incidence of Rosette disease of some groundnut varieties after inoculation.

\begin{tabular}{lll}
\hline Varieties & Spray & no spray \\
\hline 19BT & 0 & 41.7 \\
ICGV-IS-07825 & 0 & 25 \\
ICGV-IS-08872 & 0 & 25 \\
ICGV-IS-09011 & 0 & 25 \\
ICGV-IS-09982 & 0 & 16.7 \\
Mean & 0 & 26.7 \\
L.S D (5\%) & & \\
Treatment & & 15.37 \\
Varieties & & 24.31 \\
Treatment by varieties interactions & 34.38 \\
\hline
\end{tabular}

Table 6. Weight and number of grains of some groundnut varieties as affected by rosette.

\begin{tabular}{lllll}
\hline Varieties & Spray & no spray & Spray & No spray \\
\hline 19BT & 3.61 & 4.49 & 3.83 & 6 \\
ICGV-IS-07825 & 0 & 0.75 & 0 & 1.17 \\
ICGV-IS-08872 & 2.23 & 4.71 & 2.67 & 3.33 \\
ICGV-IS-09011 & 3.15 & 1.6 & 4.17 & 2.67 \\
ICGV-IS-09982 & 1.84 & 0.75 & 2.33 & 0.83 \\
Mean & 2.17 & 2.46 & 2.6 & 2.8 \\
L.S D (5\%) & & & & \\
Treatment & & 1.699 & & 2.361 \\
Verities & & 3.8 & & 3.338 \\
$\begin{array}{l}\text { Treatment by varieties } \\
\text { interactions }\end{array}$ & & & & \\
\hline
\end{tabular}

\section{References}

[1] A'Brook, J. (2007). The effect of planting date and spacing on the incidence of groundnut rosette disease and of the vector, Aphis craccivora Koch, at Mokwa, Northern Nigeria. Annals of Applied Biology 54:199-208

[2] Ambang Z, Ndongo B, Bime, Ngoh D, Maho Y, Ntsomboh $\mathrm{G}$ (2008) Effect of mycorrhizal inoculum and urea fertilizer on diseases development and yield of groundnut crops (Arachis hypogaeaL.). African Journal of Biotechnology 7(16): 2823-2827.

[3] Anon, Ann. Progr. Rep., SADC/ICRISAT Groundnut project, (1996) Chitedze Research Station, Malawi. Bock, K.R., Murant, A.F. and Rajeshwari, R. 1990. The nature of resistance in groundnut to rosette disease. Annals of Applied Biology 117:379-380

[4] Bovey R, Baggiolini M, Bolay A, Trivelli G (1994) La défense des plantescultivées. 14è édition, MaisonRustique, Paris. p 866.

[5] Blackman.R.L and V.F. Eastrop (1999) Aphids on the world trees. An identification and information Guide Wallingford: CAB international. ISBN 0-8519877-6.

[6] Charles T. Munger(2003) Application of quantitative concepts and techniques in undergraduate Biology $2^{\text {nd }}$ edition USA. Farrell, J.A.K. (2009). Effects of groundnut crop density on the population dynamics of Aphis craccivora Koch (Hemiptera, Aphididae) in Malawi.Bulletin of Entomological Research 66:317-329.

[7] Feruse .P. and M. Arkersivora., (2001). Variability of chlorophyll content under fluctuating environment. Act of technique zartech nica, Vol 4, 2001, special Number, in: the Proceedings of the international scientific conference on the occasion of the $55^{\text {th }}$ Anniversary of the Salvat Agricultural University in Nitra.

[8] Gibbons, R. W. (1997). Groundnut rosette virus. In: Diseases of Tropical Crops. Kranz, J., Schutter, J. and Koch, W., (Eds.), pp 19-21, Verlag Paul Parey, Berlin. 
[9] ICRISAT (International Crops Research Institute for the Semi-Arid Tropics), (1992). The medium term plan, 199498, Vol I. Main Report. International Crops Research Institute for the Semi-Arid Tropics (ICRISAT), Patancheru P.O., Andhra Pradesh 502 324, India.88 pp.

[10] Lane, P.W. and Payne, R.W. (1996). GENSTAT for windows: an introductory course. Second Edition, Lawes Agricultural Trust, Rothamsted Experimental Station, UK.

[11] Ma,winbon (2011) How do plants fight disease. Riverside clue USA. Murant, A. F., Robinson, D. J. and Gibbs, M. J. (1995). Genus Umbra virus. In: Virus Taxonomy Classification and Nomenclature of Viruses. Sixth Report of the International Committee on the Taxonomy of Viruses. Murphy, F.M., Fauquet, C.M., Bishop, D.H.L., Ghabrial, S.A., Jarvis, A.W., Martelli, G.P., Mayo, M.A. and Summers, M.D. (Eds.), pp 388-391, Springer-Verlag, Vienna.

[12] Naidu, R.A., Kimmins, F.M., Deom, C.M., Subrahmanyam, P., Chiyembekeza, A.J. and vander Merwe, P.J.A. (1999). Groundnut rosette: a virus disease affecting groundnut production in sub-Saharan Africa. Plant Disease 83:700-701.

[13] Olorunju, P.E., Kuhn, C.W., Demski, J.W., Misari, S.M. and Ansa, O.A. (1991). Disease reactions and yield performance of peanut genotypes grown under groundnut rosette and rosette-free field environments. Plant Disease 75: 12691270 .

[14] D. Robinson, R.A. Naidu , and F.M. Kimmins, "Aspects of the epidemiology and control of groundnut rosette disease," International Working Group on legume virus diseases. Australia. August 1999.
[15] P Subramanian, G.L.Hildebrand, , R.A.Naidu, , L.J.Reddy, and A.K.Singh, (1998). Sources of resistance to groundnut rosette disease in global groundnut germplasm.Annals of Applied Biology 132:473-474.

[16] Talukder MT, Sarwar KS, Khan S (2002) viral diseases of groundnut in Brahmaputra alluvial soil of Bangladesh. Bulletin of the Institute of Tropical Agriculture, Kyushu University 25:15-16

[17] Umeh, V. C. ,Walyyar, F. , Traoré, S., Chaibou, I. M., Omar, B., Detognon J. (2001). Farmers' opinions and influence of cultural practices on soil pest damage to groundnut in West Africa. Insect Sci. Applic. Vol. 21, No. 1, pp. 23-24.

[18] Kutama, A. S., Binta, U. B., Umar, S. and Umar, M. L. (2013): Effects of Different Levels of Nitrogen and Phosphorus Fertilizers on the Growth and Disease Incidence of Groundnut Leaf Spot Caused by Cercospora arachidicola. International Journal of Applied Research and Technology. 2(8): $94-100$.

[19] Kutama, A.S., Umar, S., Binta, U.B. and Tijjani, A. (2013): Methods For The Screening Of Sorghum Germplasm Against Sorghum Head And Loose Smuts In Nigeria. Global Advanced Research Journal of Agricultural Science,2(9):246-251

[20] Kutama, A.S., Hayatu, M., Umar, S. and M. L., Umar (2013) Evaluation of some Techniques used for the Screening of Some Cowpea (Vigna unguiculata (L.) Walp) Genotypes against Bacterial blight. Standard Res. Journal of Agricultural Sciences. 1(3):41-46 